\author{
Свистун T.B. \\ кандидат економічних наук, доцент \\ E-mail: tatyana_dud@mail.ru \\ Лянна А. C. \\ магістрант \\ кафедра економіки промисловості \\ Одеська національна академія харчових технологій \\ вул. Канатна, 112, м. Одеса, Україна, 65039 \\ E-mail: alla.lyannaya.93@mail.ru
}

\title{
ДОСЛІДЖЕННЯ РИНКУ ГРОМАДСЬКОГО ХАРЧУВАННЯ УКРАЇНИ НА ПРИКЛАДІ ОРГАНІЗАЦІЇ ХАРЧУВАННЯ ШКОЛЯРІВ
}

У статті розглянута необхідність організації шкільного харчування як одного з основних чинників підтримки здоров'я дітей. Наведені приклади організації харчування школярів за кордоном. Проаналізовано стан організації харчування школярів в Україні та запропоновано шляхи його покращення.

Ключові слова: організація харчування, шкільне харчування, діти, здоров'я.

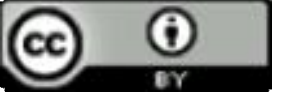

This work is licensed under a Creative Commons Attribution 4.0 International License http://creativecommons.org/licenses/by/4.0/
Постановка проблеми та її зв'язок з важливими науковими та практичними завданнями. Харчування є найважливішим фактором, що забезпечує фізичний і психічний розвиток дитини. За оцінками експертів Всесвітньої організації охорони здоров'я, стан здоров'я людини залежить від способу життя, у тому числі від харчування.

Численні дослідження стану харчування дітей шкільного віку в Україні показали, що в останні роки через низьку купівельну спроможність батьків, а також недостатнє державне фінансування шкільного харчування знизилося споживання найбільш цінних у біологічному відношенні харчових продуктів. В результаті відчувається дефіцит повноцінних білків, вітамінів, мінеральних речовин в харчуванні більшості школярів.

Актуальність дослідження проблем 3 харчуванням у школах посилюється ще й тим, що порушення в структурі харчування сприяють погіршенню стану здоров'я, зниження імунітету, погіршення уваги та пам'яті. Нераціональне та незбалансоване харчування $\epsilon$ проблемою виникнення різних захворювань. Основи здоров'я людини закладаються 3 дитинства. Здоров'я дітей і підлітків постійно продовжує погіршуватися не тільки через екологію, але в основному через фактори, пов'язані 3 харчуванням. Результати різноманітних досліджень свідчать про наявну тенденцію погіршення здоров'я школярів в Україні.

Аналіз останніх публікацій по проблемі. Дослідження проблем ресторанного господарства знайшло відображення в роботах українських ученихекономістів В.І. Карсекіна, Н.О. Власової, Г.Т. П'ятницької, А.О. Аветисової, але саме проблема шкільного харчування достатньо не висвітлена і потребує більш детального вивчення.
Саме тому метою дослідження є аналіз стану харчування школярів в Україні та пошук шляхів його покращення.

Формулювання цілей дослідження. Метою статті $\epsilon$ дослідження стану харчування школярів в Україні та пошук шляхів його покращення. Для досягнення мети дослідження було вирішено такі завдання: розглянути проблеми які існують на даний час 3 харчуванням у школах України. Запропонувати шляхи вирішення даної проблеми, розглянути як організоване шкільне харчування за кордоном.

Виклад основних результатів та їх обгрунтування. Проблема правильної організації харчування школярів має не тільки медичне, а й велике соціальне значення, тому що $є$ визначальним чинником усього наступного розвитку людини. Раціональне харчування, що відповідає фізіологічним потребам організму, який росте, забезпечує гармонійний розвиток дитини, підвищує іiі імунітет, стійкість до різних несприятливих факторів зовнішнього середовища. В останні роки прискорюються темпи навчального процесу, розширюється мережа спеціальних шкіл 3 поглибленим вивченням окремих предметів, іноземним мов. Діти, відвідуючи додаткові заняття, секції, гуртки, групи продовженого дня, нерідко проводять у школі по 8 годин. Усе це обумовлює підвищену потребу школярів в увазі, енергії та пам'яті [4].

На законодавчому рівні поліпшення харчування дітей, зокрема школярів, розглядається як питання державної ваги. Згідно ст. 25 Закону України «Про освіту» у всіх навчальних закладах повинно бути організоване харчування. Організація і відповідальність за харчування в державних навчальних закладах покладається на місцеві органи державної виконавчої влади та органи місцевого самоврядування, 
міністерства і відомства України, яким підпорядковані навчальні заклади [3].

Оскільки питання організації харчування покладено на місцеві органи державної виконавчої влади та органи місцевого самоврядування і обмежене розміром бюджетних видатків на цю статтю, на місцях часто норми харчування щодо вмісту поживних речовин і калорійності не виконуються.

Шляхом вирішення питання забезпечення гарячим харчуванням учнів 1-4 класів загальноосвітніх закладів може стати:

- збільшення суми коштів, які виділяються 3 місцевих бюджетів для харчування;

- залучення спонсорської допомоги;

- додаткове залучення батьківських коштів для надання учням повноцінного харчування.

Значно гірша ситуація за показниками охоплення гарячим харчуванням 3 5-11 класами, оскільки діти купують страви за власні кошти і на свій розсуд. Більшість учнів віддають перевагу буфетній продукції або продукції магазинів 3 наступних причин:

- небажання купувати гарячі страви через їхні смакові якості і зовнішню непривабливість;

- небажання стояти у довгій черзі під час перерви 20 хвилин;

- високу вартість страв;

- непривабливий інтер'єр їдальні; скають страви.

- незадовільний стан посуду, в якому відпу-

Послугами шкільних їдалень користується не більше $40 \%$ учнів старшої школи. Це призводить до того, що дефіцит білків, вітамінів, мінеральних речовин у раціоні учнів має негативний вплив на їхній фізичний і інтелектуальний розвиток. Часто діти витрачають гроші на шкідливі для здоров'я чіпси, сухарики, газовані напої, солодку та надто жирну їжу, так званий, фаст-фуд, що не має ніякої користі для організму.

Основними причинами неможливості організувати гаряче харчування у школах є відсутність харчоблоків (у 73\% шкіл), відсутність централізованого або незадовільний стан водопостачання (43\% шкіл), неукомплектованість харчоблоку обладнанням, віддаленість закладу і відсутність торговельної структури, невідповідність санітарно-гігієнічним вимогам [5].

Складність вирішення питань санітарногігієнічної відповідності харчо-блоків, матеріальнотехнічної забезпеченості їх обладнанням, посудом полягає також в тому, що організацією харчування школярів на $80 \%$ займаються приватні структури, для багатьох 3 яких харчування школярів не є морально відповідальним, високим завданням державною значущості, а скоріше, можливість отримати прибутки.

Кожна область країни самотужки вирішує питання організації харчування учнів навчальних закладів.

Однак організувати правильне харчування для школяра досить складно. Необхідно простежити за якістю їжі, враховуючи переваги дитини.

Розглянемо як організовано шкільне харчування за кордоном.

На сьогоднішній момент шкільне харчування в Британії не тільки одне з найкращих, воно є прикладом для наслідування. Саме в Англії найвищі вимоги і стандарти в світі до якості продуктів, що використовуються при приготуванні їжі для школярів. Саме в Англії найвищі вимоги до санітарно-гігієнічних норм, кваліфікації персоналу, використання обладнання і навіть зовнішнього вигляду страви.

Англія сьогодні не шкодує коштів на шкільне харчування, а значить не економить на здоров'ї підростаючого покоління. Столові в англійських школах оснащені всім необхідним обладнанням, у тому числі м'якими зручними стільцями, столами, відповідні віковим критерієм. В Англійських шкільних їдальнях приємна обстановка, яка сприяє швидкому засвоєнню їжі. Школяр, який обідає в такій їдальні - відволікається від шкільного навантаження і 3 задоволенням приймає їжу. Крім того завдяки цьому розвивається культура дітей [11].

У проекті фінської шкільної їдальні передбачається все до дрібниць: від виду будматеріалів, виробничого устаткування, його потужності, до кольору стін, і які картини будуть на них висіти. Вельми відрізняється від України. У Фінляндії як втім і належить розвинутій країні держава дбає не лише про задоволення первинних фізіологічних потреб людини, але i про те, в якій обстановці він буде їх задовольняти. Тим більше, що справа стосується дітей. Такої позиції дотримується Фінляндія [11].

Витрати на шкільне харчування у США становлять 56\% бюджету Мінсільгоспу які йдуть на програми харчування населення і досить велика частка на шкільне харчування. Мінсільгосп направляє гроші по штатам. Адміністрація штатів направляє ці гроші за шкільним округам. Шкільні округи закуповують продукти у місцевих підприємців, які конкурують між собою на тендерній основі [11].

Економісти в американському уряді розрахували суму витрат на одного школяра - це приблизно по 2\$в день. Цих грошей вистачає, щоб учень міг правильно і повноцінно харчуватися. Ця програма повністю прерогатива Міністерства сільського господарства. Міністерство освіти не має до харчування в американських школах ні кого відносини. Воно займається питаннями навчання, передовим досвідом викладання. В цьому їх головне призначення..

Кожні п'ять років система шкільного харчування підлягає аудиту на предмет його структури i співвідношення в харчовому раціоні білків, вуглеводів, жирів, калорійності. Згідно з останніми рекомендаціями їжа дітей в американських школах повинна забезпечувати 1/3 потреб у білку, вітамінах А, C, залі3о, кальції та калорійності (не більш ніж $30 \%$ калорій за рахунок жирів) [10].

Висновки та перспективи подальших досліджень. Для України основними напрямками покращення існуючої ситуації з організацією харчування школярів $є$ більш повне забезпечення відповідними продуктами дитячого і дієтичного харчування, всебічна державна підтримка вітчизняних виробників цієї продукції, удосконалення санітарноепідеміологічного контролю за якістю і безпекою харчових продуктів, здійснення контролю за дотриманням затверджених наборів продуктів і меню для шкіл та інших типів освітніх установ.

Для вдосконалення організації харчування школярів необхідно наукове забезпечення та розробка методичних матеріалів щодо оптимізації режиму харчування, критеріїв і методів оцінки харчового статусу, з їх включенням в стандарти медичного обслуговування школярів, а також видання інформаційних матеріалів 3 основ правильного харчування для широкої аудиторії фахівців і населення, а також програм навчання населення. 
Підводячи підсумки даної роботи, можна зробити наступні висновки:

- проблема організації шкільного харчування набула системного характеру і вирішувати іiі і надалі на місцевому рівні неприпустимо;

- відтворення системи шкільного харчування можливе тільки на професійній основі;

- прийняття програми державного масштабу, згідно якої кошти виділятимуться 3 державного бюджету і сума коштів на одного учня буде розрахова- ною $з$ урахуванням рекомендованих норм і реального рівня цін, дозволить організувати повноцінне і раціональне харчування учнів у всіх областях України.

Питання правильної і раціональної організації шкільного харчування досить складний, при його вирішенні необхідно враховувати безліч чинників і особливостей, але правильна його реалізації 3 допомогою впровадження сучасних технологій і інновацій дозволить зберегти здоров'я та працездатність школяpa і навіть поліпшити іiі.

\title{
Література
}

1. Коренєв Н.М. Здоров’я школярів, сьогодення та проблеми на перспективу / Н.М. Коренєв, Г.М. Даниленко // Охорона здоров’я України. - 2003. - № 1(8). - 49-54 с.

2. Неділько В.П. Шляхи покращення здоров'я школярів / В.П.Неділько, Т.М. Камінська, С.А. Руденко // Гігієна населених місць. - 2004. - Вип. 44. -56 с.

3. Про затвердження норм харчування у навчальних та дитячих закладах оздоровлення та відпочинку : за станом на 23.03.2016. / Кабінет міністрів України. [Електронний ресурс]. - Режим доступу: http://zakon3.rada.gov.ua/laws/show/1591-2004-п

4. Кучма В.Р. Комплексный подход к охране здоровья подростков в образовательных учреждениях, содействующих укреплению здоровья / В.Р.Кучма // Современный подросток: материалы конф., 4-5 декабря 2001 г.: тезисы докл. - М., 2001. - 28-36 с.

5. Безпека харчування: сучасні проблеми: [посібник-довідник] / [А. В. Бабюк, О. В. Макарова, М. С. Рогозинський, Л. В. Романів, О. Є. Федорова]. - Чернівці: Книги - ХХІ, 2005. - 456 с

6. Вишневский В.А. Здоровьесбережение в школе (педагогические стратегии и технологии) / В.А. Вишневский. - М.: Теория и практика физической культуры, 2002. - 270 с.

7. Хрипкова А.Г. Гигиена и здоровье школьника / Хрипкова А.Г., Колесов Д.В. - М.: Просвещение, 1988. - C. 91-99

8. Пархоменко Л.К. Медикосоциальные проблемы сохранения здоровья подростков в Украине [Электронный ресурс] / Л.К. Пархоменко // Здоровье ребенка. - 2006. - № 1. - Режим доступа: http://pediatric.mifua.com/archive/issue207/article210/.

9. Сергета І.В. Організація вільного часу та здоров'я школярів / І.В.Сергета, В.Г.Бардов. - Вінниця: РВВ ВАТ “Віноблдрукарня”, 1997. - 292 с.

10. Організація харчуання школярів за кордоном [Електронний ресурс]. - Режим доступу: http://www.profiz.ru/sec/5_2012/shkolnoe_pitanie/

11. Шкільне харчування за кордоном [Електронний ресурс]. - Режим доступу: http://www.pitportal.ru/school_lunch/4218.html

Стаття надійшла 1.02.2017 Стаття прийнята до друку 15.02.2017 Доступно в мережі Internet 31.03.2017

\author{
Свистун Т. В. \\ кандидат экономических наук, доцент \\ E-mail: tatyana dud@mail.ru \\ Лянная A.C. \\ магистрант \\ кафедра экономики промышленности \\ Одесская национальная академия пищевых технологий \\ ул. Канатная, 112, г. Одесса, Украина, 65039 \\ E-mail: alla.lyannaya.93@mail.ru
}

\section{ИССЛЕДОВАНИЕ РЫНКА ОБЩЕСТВЕННОГО ПИТАНИЯ УКРАИНЫ НА ПРИМЕРЕ ОРГАНИЗАЦИИ ПИТАНИЯ ШКОЛЬНИКОВ}

В статье рассмотрена необходимость организации школьного питания как одного из основных факторов поддержания здоровья детей. Приведены примеры организации питания школьников за границей. Проанализировано состояние организации питания школьников в Украине и предложены пути его улучшения.

Проблема правильной организации питания школьников имеет не только медицинское, но и большое социальное значение, так как является определяющим фактором всего последующего развития человека.

Для совершенствования организации питания школьников необходимо научное обеспечение и разработка методических материалов по оптимизации режима питания, критериев и методов оценки пищевого статуса, с их включением в стандарты медицинского обслуживания школьников, а также 
издание информационных материалов по основам правильного питания для широкой аудитории специалистов и населения, а также программ обучения населения.

Для Украины основным направлениям улучшения существующей ситуации с организацией питания школьников является более полное обеспечение соответствующими продуктами детского и диетического питания, всесторонняя государственная поддержка отечественных производителей этой продукции.

Ключевые слова: организация питания, школьное питание, дети, здоровье.

\author{
Svystun T. \\ Ph.D. in Economics, Associate Professor \\ E-mail: tatyana dud@mail.ru \\ Lianna A. \\ Undergraduate \\ Department of Industrial Economics \\ Odessa National Academy of Food Technologies \\ Kanatna str., 112, Odessa, Ukraine, 65039 \\ E-mail: alla.Iyannaya.93@mail.ru
}

\title{
STUDY CATERING MARKET OF UKRAINE ON THE EXAMPLE OF THE ORGANIZATION OF SCHOOL NUTRITION
}

The article considers the necessity of organizing of school feeding as one of the main factors of maintaining the health of children. Examples are given of the organization of schoolchildren's meals abroad. The state of nutrition organization of schoolchildren in Ukraine is analyzed and ways of its improvement are suggested.

The problem of the correct organization of school meals is not only medical, but has also got great social significance, since it is the determining factor of all subsequent development of man.

For Ukraine, the main direction for improving the existing situation with the organization of school meals is more complete provision of appropriate products of children's and dietary nutrition, comprehensive state support for domestic producers of these products.

To improve the organization of nutrition of schoolchildren, is necessary to have the scientific support and development of teaching materials on optimizing diet, criteria and methods of assessment of nutritional status, with inclusion of health care students, in the standards as well as providing information on the basics of proper nutrition for a wide audience of specialists and the population, and as well as the education programs of the population.

Keywords: catering, school meals, children, health.

\section{References}

1. Koreniev , N. M., \& Danylenko, H. M. (2003). Zdorov'ia shkoliariv, sohodennia ta problemy na perspektyvu . Okhorona zdorov'ia Ukrainy, 1(8), 49-54.

2. Nedilko, V. P. (2004). Shliakhy pokrashchennia zdorov'ia shkoliariv . Hihiiena naselenykh mists, 44, 56.

3. Pro zatverdzhennia norm kharchuvannia u navchalnykh ta dytiachykh zakladakh ozdorovlennia ta vidpochynku : za stanom na 23.03.2016. (2016). Retrieved February, 2017, from http://zakon3.rada.gov.ua/laws/show/15912004-p

4. Kuchma, V. R. (2001). Kompleksnыi podkhod k okhrane zdorovia podrostkov v obrazovatelnыkh uchrezhdenyiakh, sodeistvuiushchykh ukreplenyiu zdorovia. Sovremennыi podrostok, 28-36.

5. Babiuk, [A. V., Makarova, O. V., Rohozynskyi, M. S., Romaniv, L. V., \& Fedorova, O. I. (2005). Bezpeka kharchuvannia: suchasni problemy. Chernivtsi: Knyhy - XXI.

6. Vyshnevskyi, V. \%. (2002). Zdorovesberezhenye v shkole (pedahohycheskye stratehyy y tekhnolohyy). M.: Teoryia y praktyka fyzycheskoi kulturы.

7. Khrypkova, A. H., \& Kolesov, D. V. (1998). Hyhyena y zdorove shkolnyka . M.: Prosveshchenye.

8. Parkhomenko, L. K. (2006). Medykosotsyalnыe problemы sokhranenyia zdorovia podrostkov v Ukrayne . Retrieved February, 2017, from Rezhym dostupa: http://pediatric.mif-ua.com/archive/issue207/article210/.

9. Serheta, I. V., \& Bardov, V. H. (1997). Orhanizatsiia vilnoho chasu ta zdorov'ia shkoliariv . Vinnytsia: RVV VAT "Vinobldrukarnia".

10. Orhanizatsiia kharchuannia shkoliariv za kordonom . (2012). Retrieved February, 2017, from http://www.profiz.ru/sec/5 2012/shkolnoe_pitanie/

11. Shkilne kharchuvannia za kordonom. Retrieved February, 2017, from http://www.pitportal.ru/school_lunch/4218.html 